\title{
Kyzylkumite: a Finding in the Southern Baikal Region, Russia and Refinement of Its Crystal Chemical Formula
}

\author{
L. Z. Reznitsky ${ }^{a, 1}$, E. V. Sklyarov ${ }^{a}$, T. Armbruster ${ }^{b}$, L. F. Suvorova ${ }^{c}$, \\ Z. F. Uschapovskaya ${ }^{a}$, and S. V. Kanakin ${ }^{d}$ \\ ${ }^{a}$ Institute of the Earth's Crust, Siberian Branch, Russian Academy of Sciences, ul. Lermontova 128, Irkutsk, 664033 Russia \\ ${ }^{b}$ University of Bern, Friestrasse 3, CH-3012 Bern, Switzerland \\ ${ }^{c}$ Institute of Geochemistry, Siberian Branch, Russian Academy of Sciences, ul. Favorskogo 1A, Irkutsk, 664033 Russia \\ ${ }^{d}$ Geological Institute, Siberian Branch, Russian Academy of Sciences, ul. Sakh'yanovoi 6, Ulan-Ude, 670042 Russia
}

Received September 7, 2012

\begin{abstract}
Kyzylkumite has been found in $\mathrm{Cr}-\mathrm{V}$-bearing metamorphic rocks of the Sludyanka Complex, Southern Baikal region; it has been identified by X-ray powder diffraction method. This is a late secondary mineral developed after Ti-V-oxides (schreyerite, berdesinskiite) and V-bearing rutile and titanite. Kyzylkumite represents a new structural type with composition $\mathrm{Ti}_{4} \mathrm{~V}_{2}^{3+} \mathrm{O}_{10}(\mathrm{OH})_{2}$ corresponding to octahedral coordination of $\mathrm{Ti}^{4+}$ and $\mathrm{V}^{3+}$. Its unit-cell dimensions are: $a=8.4787(1), b=4.5624(1), c=10.0330(1) \AA$, $\beta=93.174(1)^{\circ}$. The ideal formula of kyzylkumite $\mathrm{Ti}_{4} \mathrm{~V}_{2}^{3+} \mathrm{O}_{10}(\mathrm{OH})_{2}$ corresponds to composition, wt $\%: 65.56$ $\mathrm{TiO}_{2}, 30.75 \mathrm{~V}_{2} \mathrm{O}_{3}, 3.69 \mathrm{H}_{2} \mathrm{O}$. Indeed, the contents (wt \%) of these constituents range from 62 to $70 \mathrm{TiO}_{2}$ and from 23 to $33 \mathrm{~V}_{2} \mathrm{O}_{3}$. Variations in contents and the $\mathrm{Ti} / \mathrm{V}$ value are caused by partial substitution $\mathrm{V}^{3+}$ for $\mathrm{V}^{4+}$, isovalent substitutions $\mathrm{Ti}^{4+}$ and $\mathrm{V}^{3+}$ for $\mathrm{V}^{4+}$ and $\mathrm{Cr}^{3+}$, respectively, and coupled substitution $\mathrm{V}^{3+}+\mathrm{OH}^{-} \hookrightarrow$ $\mathrm{Ti}^{4+}+\mathrm{O}^{2-}$. Smyslova et al. (1981) - the discovereres of kyzylkumite-assumed its composition to be the same as for schreyerite $\mathrm{V}_{2}^{3+} \mathrm{Ti}_{3} \mathrm{O}_{9}$ that principally different from kyzylkumite from the Sludyanka Complex. Therefore, re-examination of the kyzylkumite holotype or cotype from its type locality is needed.
\end{abstract}

DOI: $10.1134 / \mathrm{S} 1075701513080114$

In recent years, a few $\mathrm{Ti}-\mathrm{V}$ oxides, which are natural analogs of the so-called Andersson-Magneli phases, were found in the metamorphic rocks of the Sludyanka crystalline complex, Southern Baikal region. An oxide with the highest $\mathrm{TiO}_{2}$ content up to $70 \mathrm{wt} \%$, whose formula was approximately calculated as $\mathrm{V}_{2} \mathrm{Ti}_{4} \mathrm{O}_{11}$ (if total vanadium is occurs as $\mathrm{V}_{2} \mathrm{O}_{3}$ ) was attributed to these oxides. However, its $\mathrm{X}$-ray powder diffraction pattern is consistent with that of kyzylkumite $\mathrm{V}_{2} \mathrm{Ti}_{3} \mathrm{O}_{9}$ discovered in 1980 at an uranium deposit in Kyzyl Kum (Smyslova et al., 1981). The subsequent single crystal X-ray diffraction and additional series of electron microprobe analyses revealed basic distinctions in composition and formula from the original description of kyzylkumite. Nevertheless, the Slyudynka mineral was referred to kyzylkumite on the basis of identical $d$-spacings and unit-cell dimensions (see below). Some of arising problems are discussed in conclusions to this paper.

Kyzylkumite was found in the $\mathrm{Cr}-\mathrm{V}$-bearing quartz-diopside rock, where schreyerite, berdesinskiite, and $\mathrm{Ba}-\mathrm{Ti}-\mathrm{V}$ minerals batisivite and ankangite-

\footnotetext{
${ }^{1}$ Corresponding author: L.Z. Reznitsky. E-mail: garry@crust.irk.ru
}

type phase had been described previously (Döbelin et al., 2006; Reznitsky et al., 2008, 2010; Armbruster et al., 2008, 2009). In addition to these minerals and rock-forming quartz and $\mathrm{Cr}-\mathrm{V}$-bearing diopside, the following accessories were identified in the rock: members of the chromite-kulsonite, eskolaite-karelianite and dravite-vanadiumdravite series, di- and trioctahedral $\mathrm{Cr}-\mathrm{V}$-bearing micas, goldmanite, $\mathrm{V}$-bearing titanite and rutile, plagioclase, barite, zircon, and uraninite.

A few tens of kyzylkumite grains were determined in samples of electromagnetic fraction on a scanning electron microscope equipped with EDS. The most homogeneous and inclusion-free grains were selected for the X-ray structural study; the others were used for electron microprobe examination as polished samples.

Kyzylkumite occurs as nearly isometric grains (up to $0.1-0.2 \mathrm{~mm}$ in size) mostly rough, porous, and slaglike; they contain mineral inclusions or are intergrown with other minerals (Fig. 1). The much less frequent compact grains with elements of faceting were probably inherited by pseudomorphous replacement of other minerals. As was established in reflected light and on electron microprobe, kyzylkumite is a late, 

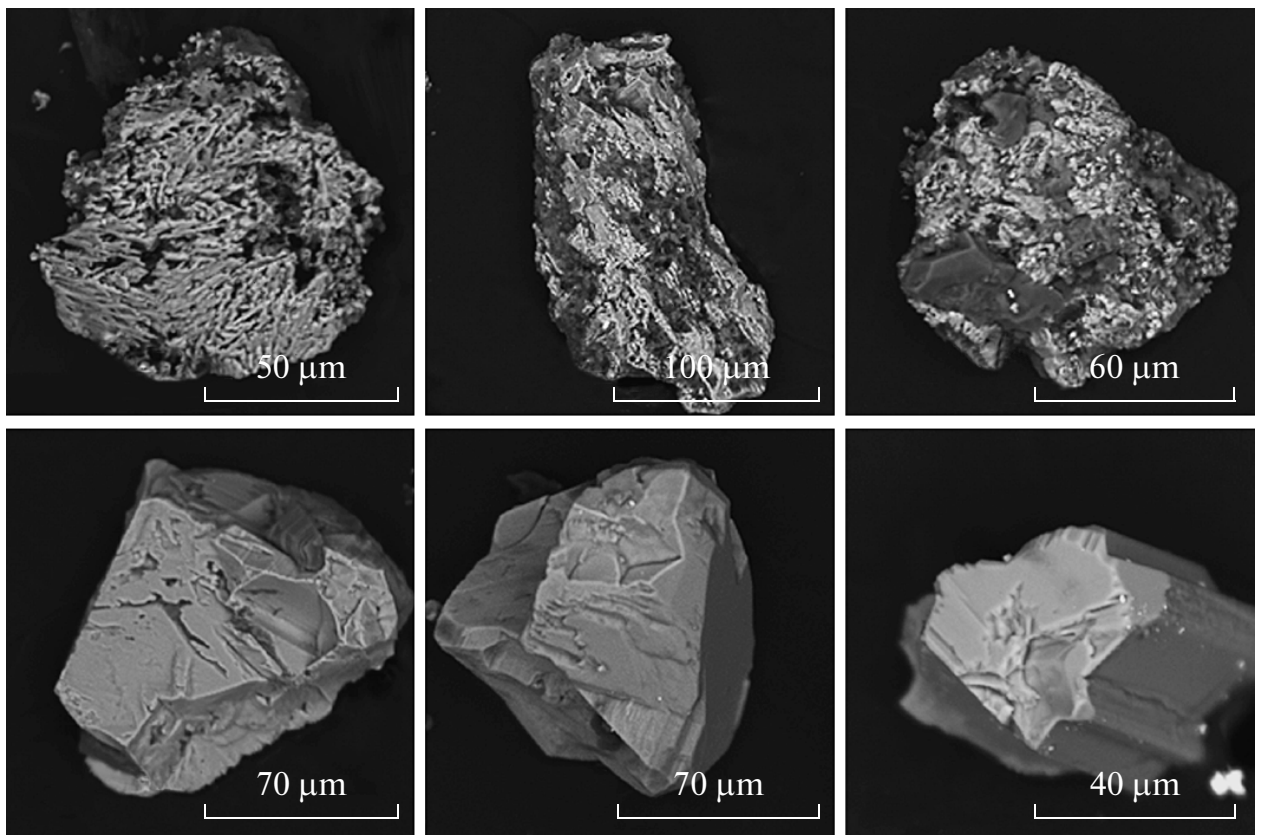

Fig. 1. Morphology of kyzylkumite grains (SEM images): slag-shaped grains as usual for kyzylkumite are shown in the upper row; the rare type of massive grains with elements of faceting is shown in the lower row. Dark inclusions are silicate minerals.
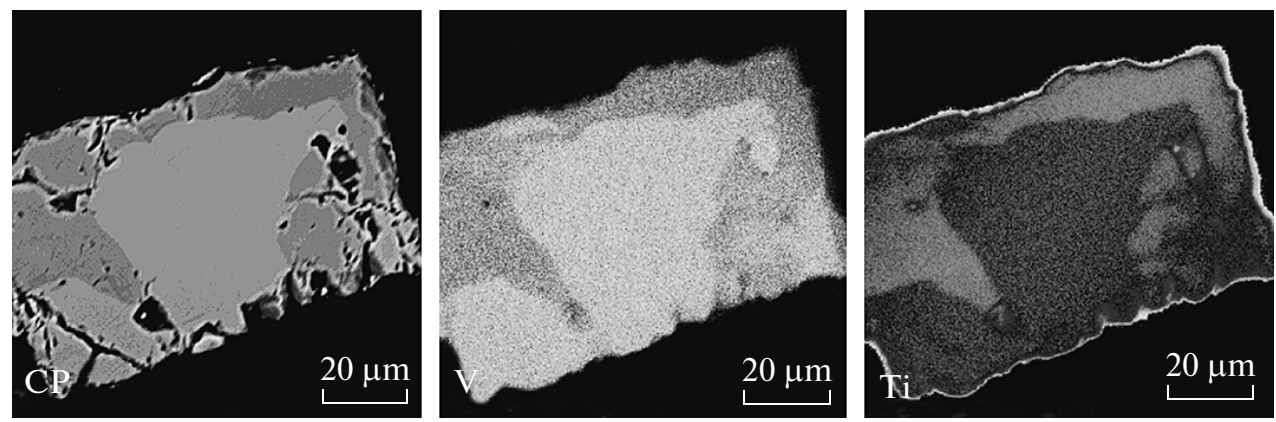

Fig. 2. Replacement of schreyerite by kyzylkumite: (CP) BSE image, (V) and (Ti) X-ray distribution maps of V and Ti, where schreyerite is lighter and darker than kyzylkumite, respectively.

secondary oxide developed after other $\mathrm{V}-\mathrm{Ti}$ - or V-bearing oxides (schreyerite, berdesinskiite, and rutile) and titanite. In some cases, the replacement starts from formation of kyzylkumite rims (Fig. 2). The more frequent replacement of the entire grain apparently used various defects and resulted in spotted character of kyzylkumite with variable relationships between newly formed and replaced minerals. An example of kyzylkumite with relict titanite is shown in Fig. 3. At high degree of replacement, the interphase boundaries of fine relics of $\mathrm{V}-\mathrm{Ti}$ oxides are poorly discernible and primary minerals are distinguished only by elevated contents of minor constituents. These are $\mathrm{Cr}_{2} \mathrm{O}_{3}$ and/or $\mathrm{Fe}_{2} \mathrm{O}_{3}$ in schreyerite and berdesinskiite, $\mathrm{Nb}_{2} \mathrm{O}_{5}$ and/or $\mathrm{WO}_{3}$ in rutile, whose concentrations are an order of magnitude higher than in newly-formed kyzylkumite. Kyzylkumite with relics of rutile, which are marked by distribution of W, is shown in Fig. 4.

The single-crystal X-ray diffraction data for kyzylkumite were collected on a Bruker APEX II diffractometer with CCD detector (MoK $K_{\alpha}$ radiation). The crystal structure was solved and refined in acentric space group $P c[R 1=2.39 \%$; 936 unique reflections with $I>2 \sigma(I), 105$ parameters] using the SHELX software package (Sheldrick, 2008). The arrangement of atoms in the structure of kyzylkumite corresponds to a new structural type: $\mathrm{Ti}_{4} \mathrm{~V}_{2}^{3+} \mathrm{O}_{10}(\mathrm{OH})_{2}$ with octahedral coordination of $\mathrm{Ti}^{4+}$ and $\mathrm{V}^{3+}$. The crystal structure of kyzylkumite will be discussed in detail in a separate article; here, we briefly characterize its features.

The crystal structure of kyzylkumite is based on hexagonal close packing of oxygen atoms with the layers parallel to (010). Such type of packing gives rise to 



Fig. 3. Grain of kyzylkumite with relics of replaced titanite: (CP) BSE image; (Ca, Ti, Si) X-ray distribution maps of Ca, Ti, and $\mathrm{Si}$. Titanite is clearly seen in Ca and Si maps. Bright spot in the BSE image and Si map is barite and quartz, respectively.


Fig. 4. BSE image (CP) and $X$-ray distribution maps of $\mathrm{Ti}, \mathrm{W}$, and $\mathrm{V}$ in relics of $\mathrm{V}$ - and $\mathrm{W}$-bearing rutile in kyzylkumite. The relics are not displayed in the Ti map because of similar $\mathrm{TiO}_{2}$ contents, weakly seen in the $\mathrm{V}$ map and BSE image, but clearly displayed in the $\mathrm{W}$ map (the $\mathrm{WO}_{3}$ content in rutile is $6-7 \mathrm{wt} \%$ ). Bright white segregations in the BSE image is barite. 

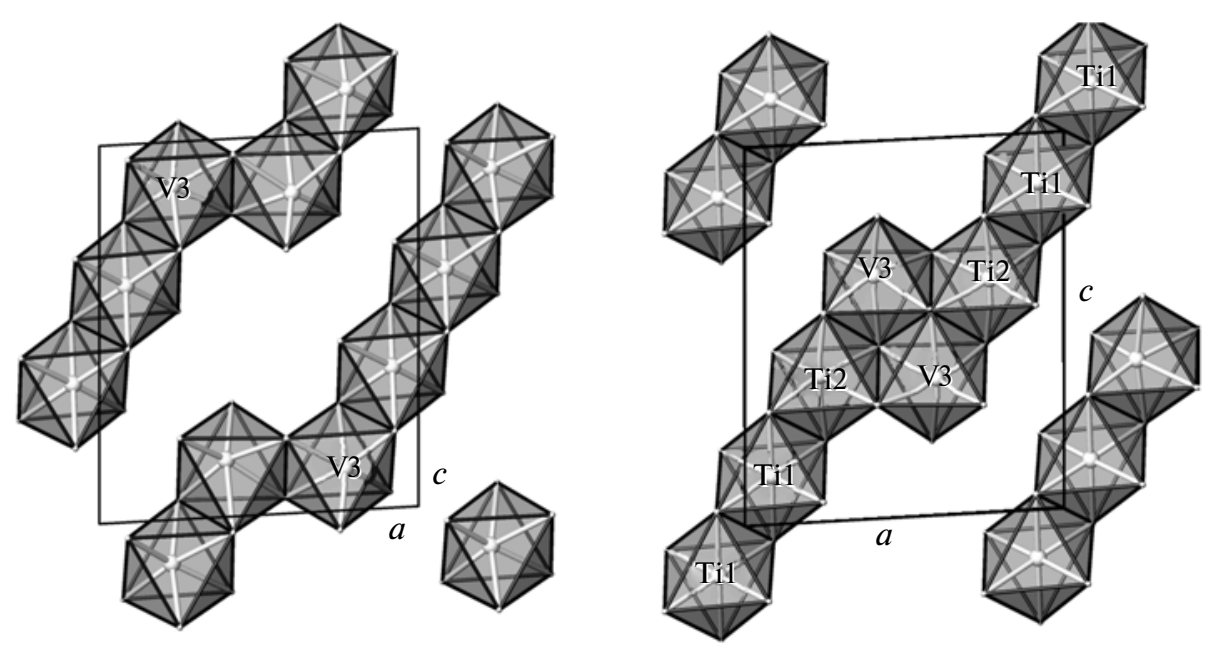

Fig. 5. Arrangement of octahedra in structure of kyzylkumite in the adjacent layers parallel to (010).

common twining in crystals owing to rotation through $120^{\circ}$ around axis $b$. Due to polysynthetic twins, the unit-cell dimensions of kyzylkumite were initially multiply increased and determined as $a=33.80, b=$ 4.578, $c=19.99 \AA, \beta=94.4^{\circ}$ (Smyslova et al., 1981). We have also obtained similar unit-cell dimensions without allowance for twining, but after appropriate corrections, the real parameters were $a=8.4787(1)$, $b=4.5624(1), c=10.0330(1) \AA, \beta=93.174(1)^{\circ}$. In accordance with type of oxygen packing in the structure of kyzylkumite, two layers are arranged parallel to $b$ due to gliding along planes $(c)$ perpendicular to $b$. Edge-shared octahedra make up the stepped chains parallel to [101], which, in turn, are formed by fragments of straight chains of four octahedra with lateral jointing of each subsequent fragment (Fig. 5). Clusters of four octahedra with three shared edges within the layer (010) are formed at junctions of the straight chain fragments. These octahedra (M3-M6) are strongly distorted because of shifting cations from the central site owing to repulsion $\mathrm{Me}^{4+}-\mathrm{Me}^{3+},{ }^{4+}$ in neighboring polyhedra. In M3-M6 octahedra (average distance $\mathrm{M}-\mathrm{O}=1.97-2.00 \AA)$, the difference $(\Delta)$ between minimal and maximal distances $\mathrm{Me}^{4+}-\mathrm{O}$ is $0.2-0.3 \AA$. Octahedra $\mathrm{M} 1$ and $\mathrm{M} 2$ (average distance $\mathrm{Me}^{4+}-\mathrm{O}=$ $1.97-1.98 \AA$ A $)$ arranged in the center of straight chains are much less distorted and $\Delta$ is 0.02 and 0.05 , respectively.

The X-ray powder diffraction data for kyzylkumite (three grains were measured separately; the results were reproducible) are given in Table 1 . The indexing was performed by the unit-cell dimensions obtained as a result of single crystal study.

The chemical composition of kyzylkumite was determined on a Superprobe JXA-820 JEOL electron microprobe, operating at an accelerating voltage of $20 \mathrm{kV}$, a current of $20 \mathrm{nA}$, a beam diameter of $1 \mu \mathrm{m}$; analyst L.F. Suvorova. The following standards were used: metal oxides $(\mathrm{Fe}, \mathrm{Cr}, \mathrm{Ti}, \mathrm{V})$, chrome spinel $(\mathrm{Mg}$, $\mathrm{Al})$, diopside $(\mathrm{Ca})$, garnet $(\mathrm{Si})$, rhodonite $(\mathrm{Mn})$, metallic $\mathrm{Nb}(\mathrm{Nb})$, and $\mathrm{FeWO}_{4}(\mathrm{~W})$. It must be emphasized that kyzylkumite is brittle, readily crumbled out and poorly polished. In the polished samples, most grains look like a coarse sieve. Because of poor polishing, small areas suitable for measurement hampered high-quality analyses. Fifty three of one hundred and eight point analyses in fifty two grains have totals ranging from 99 to $101 \mathrm{wt} \%$, most of which were obtained on compact grains. Totals of other analyses range from 96-97 to 98-99 wt \%; however, typical proportions of cations remain the same as in good analyses. The contents of major constituents $\mathrm{TiO}_{2}$ and $\mathrm{V}_{2} \mathrm{O}_{3}$ range from 62 to 70 and from 23 to $33 \mathrm{wt} \%$, respectively. $\mathrm{Cr}_{2} \mathrm{O}_{3}$ (up to $1-3 \mathrm{wt} \%$ ) and $\mathrm{Nb}_{2} \mathrm{O}_{5}$ (a few tenths percent) are detected permanently. Many grains are heterogeneous in composition, but zoning was not observed. The interrelated variations in $\mathrm{Cr}$ and $\mathrm{V}$ contents are irregular (spotted) (Fig. 6). The typical compositions characterizing the main range of $\mathrm{TiO}_{2}$ and $\mathrm{V}_{2} \mathrm{O}_{3}$ are given in Table 2.

In some cases, the compositional features of kyzylkumite inherited from replaced mineral are noticeable. For example, anomalously high $\mathrm{CaO}, \mathrm{SiO}_{2}$, or $\mathrm{Nb}_{2} \mathrm{O}_{5}$ content are detected in kyzylkumite developed after titanite, although in this case, submicroscopic inclusions of quartz and calcite, which are probably resulted from replacement of titanite and indiscernible under high magnification cannot be ruled out. Some varieties of berdesinskiite and schreyerite are enriched in $\mathrm{Cr}_{2} \mathrm{O}_{3}$ and/or $\mathrm{FeO}$ up to 20-21 and 8-9 wt \%, respectively (Döbelin et al., 2006; Reznitsky et al., 2009). The compositions of kyzylkumite replacing these minerals have $\mathrm{Cr}_{2} \mathrm{O}_{3}$ and/or $\mathrm{FeO}$ concentrations, which obviously differ from typical values. $\mathrm{Nb}_{2} \mathrm{O}_{5}$ and/or $\mathrm{WO}_{3}$ can be inherited from rutile, where its content reach 
Table 1. X-ray powder diffraction data on kyzylkumite

\begin{tabular}{|c|c|c|c|c|c|c|}
\hline \multicolumn{4}{|c|}{ Kyzylkumite, Sludyanka } & \multicolumn{3}{|c|}{ Kyzylkumite, Kyzylkym desert (Smyslova et al., 1981) } \\
\hline$I$ & $d_{\mathrm{obs}}, \AA$ & $d_{\text {calc }}, \AA$ & $h k l$ & $I$ & $d(\AA)$ & $h k l$ \\
\hline 3 & 4.06 & 4.02 & 110 & 25 & 4.15 & 012 \\
\hline 10 & 3.67 & 3.69 & 111 & 80 & 3.70 & 511 \\
\hline 10 & 2.92 & 2.93 & 211 & 100 & 2.92 & 713 \\
\hline 6 & 2.74 & $n / i$ & - & & & \\
\hline 6 & 2.59 & 2.59 & 212 & 50 & 2.60 & $71 \overline{5}$ \\
\hline & & & & 40 & 2.510 & $12.0 . \overline{4}$ \\
\hline 5 & 2.50 & 2.50 & 004 & 30 & 2.495 & 008 \\
\hline & & & & 5 & 2.390 & 12.0 .4 \\
\hline & & & & 15 & 2.310 & $51 \overline{7}$ \\
\hline 10 & 2.20 & 2.20 & 120 & 48 & 2.192 & 018 \\
\hline 5 & 2.10 & 2.10 & 114 & 24 & 2.115 & $12.1 .4,6.2 .1$ \\
\hline & & & & 50 & 1.692 & $12.2 . \overline{4}$ \\
\hline 10 & 1.687 & 1.686 & 024 & 65 & 1.682 & 028 \\
\hline 10 & 1.655 & 1.655 & 106 & 55 & 1.650 & $12.2 .4,19.1 .0$ \\
\hline 3 & 1.578 & 1.578 & 502 & 25 & 1.577 & $20.1 .0,20.1 . \overline{1}$ \\
\hline 4 & 1.471 & 1.471 & 125 & 20 & 1.469 & 12.0. $\overline{1} . \overline{2}, 23.0 .0$ \\
\hline 4 & 1.406 & 1.406 & 513 & $20 \mathrm{br}$ & $1.415-1.395$ & $24.0 .0,12.0 .12,12.1 . \overline{12}$ \\
\hline & & & & 15 & 1.372 & 336 \\
\hline & & & & 15 & 1.360 & 0.1 .14 \\
\hline 2 & 1.109 & 1.109 & 136 & & & \\
\hline \multicolumn{7}{|c|}{ Unit-cell dimensions } \\
\hline & & & $a(\AA)$ & $8.484(3)$ & 33.80 & \\
\hline & & & $b(\AA)$ & $4.562(1)$ & 4.578 & \\
\hline & & & $c(\AA)$ & $10.029(2)$ & 19.99 & \\
\hline & & & $\beta\left(^{\circ}\right)$ & $93.22(4)$ & 93.40 & \\
\hline & & & $V\left(\AA^{3}\right)$ & $387.5(3)$ & 3088 & \\
\hline
\end{tabular}

X-ray powder diffraction data were collected with a RKD-53.7 mm camera, $\mathrm{Fe} K_{\alpha}$ radiation. A grain was crushed and rolled up into a ball of rubber adhesive. Because of small size, the sample was analyzed without an internal standard. Film loading is asymmetric; $n / i$ is not indexed. Analyst Z.F. Ushchapovskaya.

6-8 wt \%. The examples of these deviations from typical composition are given in Table 3.

The ideal formula of kyzylkumite $\mathrm{Ti}_{4} \mathrm{~V}_{2}^{3+} \mathrm{O}_{10}(\mathrm{OH})_{2}$ requires the following composition, wt $\%: 65.56 \mathrm{TiO}_{2}$, $30.75 \mathrm{~V}_{2} \mathrm{O}_{3}, 3.69 \mathrm{H}_{2} \mathrm{O}$ with the $\mathrm{Ti} / \mathrm{V}$ value 2 (in atomic number). As seen from Tables 2 and 3 , the real range of composition is significantly wider than acceptable analytical errors. The histograms of $\mathrm{TiO}_{2}$ content (for 53 analyses with total $100 \pm 1 \mathrm{wt} \%)$ and the $\mathrm{Ti} /(\mathrm{V}+$ $\mathrm{Cr}$ ) ratio (for the whole data array) are shown in Figs. 7 and 8 . The maximum of the $\mathrm{TiO}_{2}$ frequency distribution is slightly shifted to the lower contents (range 64$65 \mathrm{wt} \%)$, but average content $(65.62 \mathrm{wt} \%)$ is consistent with theoretical. Maximum of the $\mathrm{Ti} /(\mathrm{V}+\mathrm{Cr})$ frequency distribution is consistent with the ideal formula (taking into account isomorphic substitution $\mathrm{V}^{3+} \longleftrightarrow$
$\mathrm{Cr}^{3+}$ ), but the distribution slightly differs from normal distribution (peak is shifted to the higher values).

The formulae of the compositions with the $\mathrm{TiO}_{2}$ content below theoretical value (less than 4 apfu) are calculated in assumption that a part of $\mathrm{V}$ is tetravalent. This is consistent with compositions of other Ti-V and $\mathrm{Ba}-\mathrm{Ti}-\mathrm{V}$ oxides associated with kyzylkumite and almost always containing $\mathrm{Ti}^{4+}$ substituting $\mathrm{V}^{3+}$ and $\mathrm{V}^{4+}$ (Döbelin et al., 2006; Reznitsky et al., 2010; Armbruster et al., 2009). The substitution $\mathrm{Ti}^{4+} \longleftrightarrow \mathrm{V}^{4+}$ is expressed in the maximum of the $\left(\mathrm{Ti}+\mathrm{V}^{4+}\right) /(\mathrm{Cr}+$ $\mathrm{V}^{3+}$ ) frequency distribution close to 2 , however, asymmetry of the distribution increases. If negative correlation between $\mathrm{Ti}$ and $(\mathrm{V}+\mathrm{Cr}$ ) (Fig. 9) takes into account, a partial coupled substitution $\mathrm{Ti}^{4+}+\mathrm{O}^{2-} \longleftrightarrow$ $\mathrm{V}^{3+}+\mathrm{OH}^{-}$in kyzylkumite (see Tables 2 and 3 ) should 

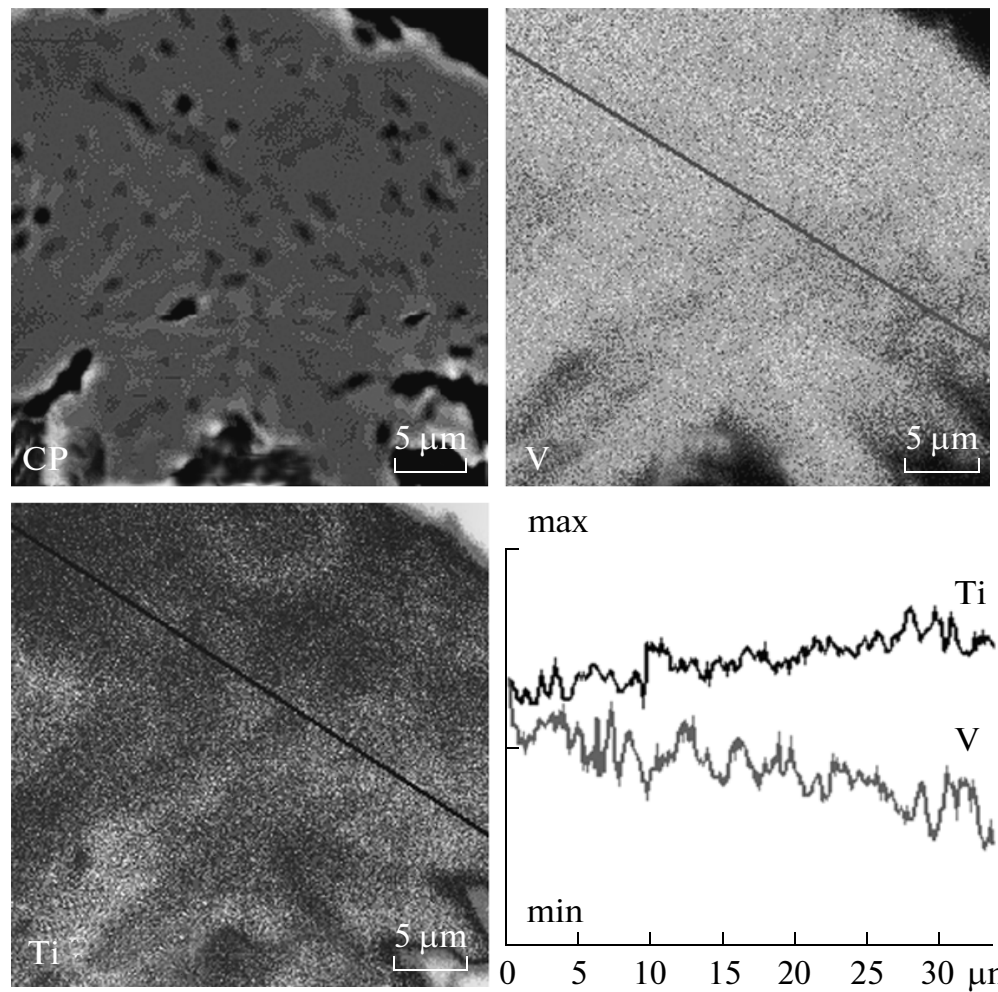

$\max$

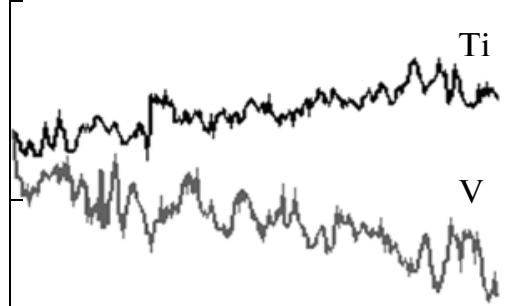

$\min$

$\begin{array}{lllllll}0 & 5 & 10 & 15 & 20 & 25 & 30 \mu \mathrm{m}\end{array}$

Fig. 6. Fragment of a heterogeneous kyzylkumite grain.

be assumed. Thus, three types of isomorphic substitution are possible in kyzylkumite: $\mathrm{Ti}^{4+} \longleftrightarrow \mathrm{V}^{4+}, \mathrm{V}^{3+}+$ $\mathrm{OH}^{-} \longleftrightarrow \mathrm{Ti}^{4+}+\mathrm{O}^{2-}$ and $\mathrm{V}^{3+} \longleftrightarrow \mathrm{Cr}^{3+}$ (without allowance for minor constituents).

The relationships of kyzylkumite with other Ti-V oxides indicate late and relatively low temperature origin of the mineral in compliance with its mode of

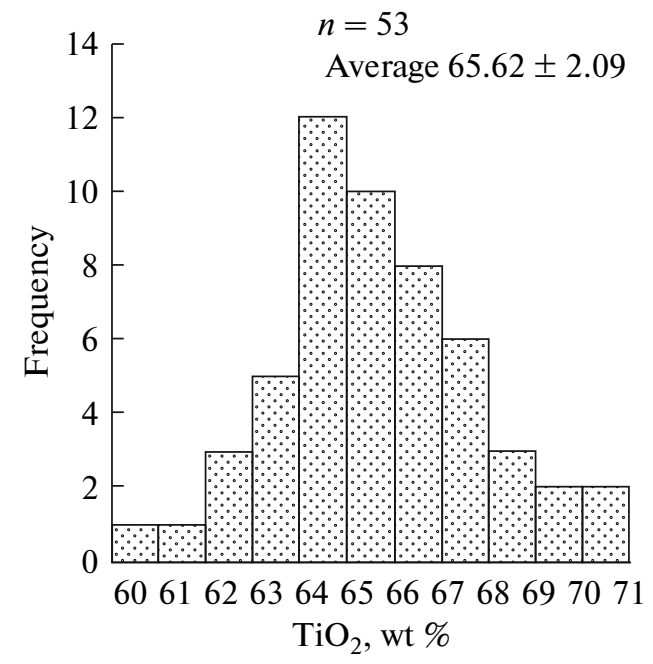

Fig. 7. Histogram of $\mathrm{TiO}_{2}$ in kyzylkumite. occurrence at the deposit in Kyzyl Kum (veinlets in chert and association with chlorite). However, the minerals markedly differ in chemical composition (ultimately, in formula), although the Sludyanka mineral and Kyzyl Kum holotype are identical in the unitcell dimensions (if these parameters are calculated taking twining into account). According to Smyslova

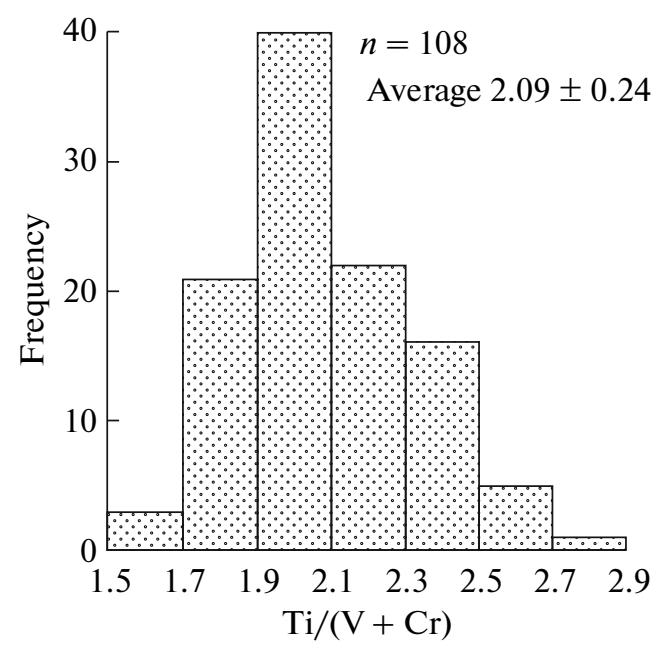

Fig. 8. Histogram of $\mathrm{Ti} /(\mathrm{Vr}+\mathrm{Cr})$ in kyzylkumite. 
Table 2. Representative electron microprobe data on kyzylkumite, wt \%

\begin{tabular}{|c|c|c|c|c|c|c|c|c|c|}
\hline Component & 1 & 2 & 3 & 4 & 5 & 6 & 7 & 8 & 9 \\
\hline $\mathrm{SiO}_{2}$ & 0.04 & 0.00 & 0.02 & 0.02 & 0.01 & 0.00 & 0.00 & 0.02 & 0.07 \\
\hline $\mathrm{TiO}_{2}$ & 60.57 & 63.14 & 63.36 & 64.02 & 64.68 & 65.14 & 65.47 & 65.66 & 66.88 \\
\hline $\mathrm{Al}_{2} \mathrm{O}_{3}$ & 0.04 & 0.04 & 0.03 & 0.05 & 0.01 & 0.03 & 0.12 & 0.04 & 0.00 \\
\hline $\mathrm{V}_{2} \mathrm{O}_{3}$ & 32.70 & 31.21 & 32.13 & 29.06 & 28.02 & 29.74 & 28.65 & 25.74 & 27.98 \\
\hline $\mathrm{Cr}_{2} \mathrm{O}_{3}$ & 2.18 & 1.44 & 0.80 & 2.69 & 2.48 & 1.08 & 1.41 & 4.35 & 1.26 \\
\hline $\mathrm{FeO}$ & 0.01 & 0.02 & 0.00 & 0.25 & 0.36 & 0.00 & 0.00 & 0.00 & 0.03 \\
\hline $\mathrm{MnO}$ & 0.00 & 0.00 & 0.01 & 0.03 & 0.00 & 0.00 & 0.02 & 0.01 & 0.00 \\
\hline $\mathrm{MgO}$ & 0.00 & 0.00 & 0.08 & 0.00 & 0.02 & 0.03 & 0.00 & 0.08 & 0.03 \\
\hline $\mathrm{CaO}$ & 0.00 & 0.01 & 0.00 & 0.01 & 0.01 & 0.02 & 0.00 & 0.01 & 0.01 \\
\hline $\mathrm{Nb}_{2} \mathrm{O}_{5}$ & 0.09 & 0.10 & 0.15 & 0.03 & 0.33 & 0.02 & 0.18 & 0.14 & 0.11 \\
\hline $\mathrm{WO}_{3}$ & n.d. & n.d. & n.d. & n.d. & n.d. & n.d. & n.d. & 0.08 & n.d. \\
\hline Total & 95.63 & 95.96 & 96.58 & 96.16 & 95.92 & 96.06 & 95.85 & 96.13 & 96.37 \\
\hline $\mathrm{V}_{2} \mathrm{O}_{3}^{*}$ & 28.44 & 29.18 & 29.82 & 27.41 & 27.47 & 29.42 & 28.65 & 25.74 & 27.98 \\
\hline $\mathrm{VO}_{2}^{*}$ & 4.72 & 2.25 & 2.55 & 1.83 & 0.61 & 0.35 & - & - & - \\
\hline $\mathrm{H}_{2} \mathrm{O}^{*}$ & 3.68 & 3.68 & 3.71 & 3.69 & 3.67 & 3.69 & 3.64 & 3.65 & 3.54 \\
\hline Total & 99.77 & 99.86 & 100.53 & 100.03 & 99.65 & 99.78 & 99.49 & 99.78 & 99.91 \\
\hline \multicolumn{10}{|c|}{ Atoms per formula unit (calculated on the basis of 6 cations and $12 \mathrm{O}$ atoms) } \\
\hline $\mathrm{Si}$ & 0.003 & - & 0.002 & 0.002 & 0.001 & - & - & 0.002 & 0.006 \\
\hline $\mathrm{Ti}$ & 3.712 & 3.862 & 3.848 & 3.908 & 3.966 & 3.982 & 4.016 & 4.018 & 4.082 \\
\hline $\mathrm{V}^{4+}$ & 0.279 & 0.132 & 0.149 & 0.107 & 0.036 & 0.021 & - & - & - \\
\hline $\mathrm{V}^{3+}$ & 1.858 & 1.903 & 1.931 & 1.784 & 1.796 & 1.918 & 1.873 & 1.679 & 1.820 \\
\hline $\mathrm{Al}$ & 0.004 & 0.004 & 0.003 & 0.005 & 0.001 & 0.003 & 0.012 & 0.004 & - \\
\hline $\mathrm{Cr}$ & 0.140 & 0.093 & 0.051 & 0.173 & 0.160 & 0.069 & 0.091 & 0.280 & 0.081 \\
\hline $\mathrm{Fe}$ & 0.001 & 0.001 & - & 0.017 & 0.025 & - & - & - & 0.002 \\
\hline $\mathrm{Mn}$ & - & - & 0.001 & 0.002 & - & - & 0.001 & 0.001 & - \\
\hline $\mathrm{Mg}$ & - & - & 0.010 & - & 0.002 & 0.004 & - & 0.010 & 0.004 \\
\hline $\mathrm{Ca}$ & - & 0.001 & - & 0.001 & 0.001 & 0.002 & - & 0.001 & 0.001 \\
\hline $\mathrm{Nb}$ & 0.003 & 0.004 & 0.005 & 0.001 & 0.012 & 0.001 & 0.007 & 0.005 & 0.004 \\
\hline $\mathrm{W}$ & - & - & - & - & - & - & - & 0.002 & - \\
\hline Total & 6.000 & 6.000 & 6.000 & 6.000 & 6.000 & 6.000 & 6.000 & 6.000 & 6.000 \\
\hline $\mathrm{OH}$ & 2.000 & 2.000 & 2.000 & 2.000 & 2.000 & 2.000 & 1.984 & 1.982 & 1.918 \\
\hline Component & 10 & 11 & 12 & 13 & 14 & 15 & 16 & 17 & 18 \\
\hline $\mathrm{SiO}_{2}$ & 0.02 & 0.03 & 0.01 & 0.14 & 0.07 & 0.04 & - & - & - \\
\hline $\mathrm{TiO}_{2}$ & 66.97 & 67.40 & 68.07 & 68.45 & 69.54 & 70.21 & 66.21 & 70.89 & 61.70 \\
\hline $\mathrm{Al}_{2} \mathrm{O}_{3}$ & 0.05 & 0.06 & 0.09 & 0.09 & 0.03 & 0.00 & 0.06 & - & - \\
\hline $\mathrm{V}_{2} \mathrm{O}_{3}$ & 25.02 & 28.30 & 27.60 & 25.68 & 23.06 & 26.60 & 24.71 & 27.42 & 36.20 \\
\hline $\mathrm{Cr}_{2} \mathrm{O}_{3}$ & 3.34 & 1.25 & 0.66 & 0.91 & 3.15 & 0.37 & 1.72 & - & 1.20 \\
\hline $\mathrm{FeO}$ & 0.01 & 0.00 & 0.05 & 0.02 & 0.00 & 0.06 & 1.37 & 1.11 & 0.70 \\
\hline $\mathrm{MnO}$ & 0.00 & 0.00 & 0.00 & 0.00 & 0.00 & 0.00 & - & 0.09 & - \\
\hline $\mathrm{MgO}$ & 0.05 & 0.06 & 0.00 & 0.03 & 0.05 & 0.00 & - & - & - \\
\hline
\end{tabular}


Table 2. (Contd.)

\begin{tabular}{|c|c|c|c|c|c|c|c|c|c|}
\hline Component & 10 & 11 & 12 & 13 & 14 & 15 & 16 & 17 & 18 \\
\hline $\mathrm{CaO}$ & 0.01 & 0.01 & 0.01 & 0.04 & 0.01 & 0.02 & - & - & - \\
\hline $\mathrm{Nb}_{2} \mathrm{O}_{5}$ & 0.55 & 0.26 & 0.16 & 0.41 & 0.27 & 0.02 & - & - & - \\
\hline $\mathrm{WO}_{3}$ & n.d. & n.d. & n.d. & n.d. & n.d. & n.d. & - & - & - \\
\hline Total & 96.02 & 97.37 & 96.65 & 95.77 & 96.18 & 97.32 & 94.07 & 98.40 & 99.80 \\
\hline $\mathrm{V}_{2} \mathrm{O}_{3}^{*}$ & 25.02 & 28.30 & 27.60 & 25.68 & 23.06 & 26.60 & 24.71 & 27.42 & - \\
\hline $\mathrm{VO}_{2}^{*}$ & - & - & - & - & - & - & - & - & - \\
\hline $\mathrm{H}_{2} \mathrm{O}^{*}$ & 3.46 & 3.59 & 3.43 & 3.27 & 3.19 & 3.26 & 3.71 & 3.83 & - \\
\hline Total & 99.48 & 100.96 & 100.08 & 99.04 & 99.37 & 100.58 & 97.78 & 102.33 & - \\
\hline \multicolumn{10}{|c|}{ Atoms per formula unit (calculated on the basis of 6 cations and 120 atoms) } \\
\hline $\mathrm{Si}$ & 0.002 & 0.002 & 0.001 & 0.011 & 0.006 & 0.003 & - & - & - \\
\hline $\mathrm{Ti}$ & 4.111 & 4.073 & 4.146 & 4.212 & 4.264 & 4.250 & 4.146 & 4.192 & 3.014 \\
\hline $\mathrm{V}^{4+}$ & - & - & - & - & - & - & - & - & - \\
\hline $\mathrm{V}^{3+}$ & 1.638 & 1.823 & 1.792 & 1.685 & 1.507 & 1.716 & 1.649 & 1.729 & 1.886 \\
\hline $\mathrm{Al}$ & 0.005 & 0.006 & 0.009 & 0.009 & 0.003 & 0.000 & 0.006 & - & - \\
\hline $\mathrm{Cr}$ & 0.216 & 0.079 & 0.042 & 0.059 & 0.203 & 0.024 & 0.113 & - & 0.062 \\
\hline $\mathrm{Fe}$ & 0.001 & - & 0.003 & 0.001 & - & 0.004 & 0.086 & 0.073 & 0.034 \\
\hline $\mathrm{Mn}$ & - & - & - & - & - & - & - & 0.006 & - \\
\hline $\mathrm{Mg}$ & 0.006 & 0.007 & - & 0.004 & 0.006 & - & - & - & - \\
\hline $\mathrm{Ca}$ & 0.001 & 0.001 & 0.001 & 0.004 & 0.001 & 0.002 & - & - & - \\
\hline $\mathrm{Nb}$ & 0.020 & 0.009 & 0.006 & 0.015 & 0.010 & 0.001 & - & - & - \\
\hline $\mathrm{W}$ & - & - & - & - & - & - & - & - & - \\
\hline Total & 6.000 & 6.000 & 6.000 & 6.000 & 6.000 & 6.000 & 6.000 & 6.000 & 4.996 \\
\hline $\mathrm{OH}$ & 1.888 & 1.928 & 1.854 & 1.787 & 1.736 & 1.750 & 1.854 & 1.808 & - \\
\hline
\end{tabular}

(1-15) This study; (16) Raade and Balić-Zunić (2006), total $\mathrm{Fe}$ as $\mathrm{Fe}_{2} \mathrm{O}_{3}$; (17) Vihanti deposit (Sergeeva et al., 2011); (18) deposit in Kyzyl Kum (Smyslova et al., 1981), formula is calculated on the basis of $9 \mathrm{O}$ atoms. * calculated content; n.d., not detected.

et al (1981), the chemical composition of kyzylkumite is similar to that of schreyerite $\mathrm{V}_{2} \mathrm{Ti}_{3} \mathrm{O}_{9}$, where the whole $\mathrm{V}$ is trivalent, the $\mathrm{Ti} / \mathrm{V}_{3}$ value is 1.5 , and hydroxyl ion is absent (see Table 2, anal 18).

It is noteworthy that the question concerning the chemical composition of the Kyzyl Kum kyzylkumite has been already arisen. Some years ago, Ti-V oxide with the unit-cell dimensions (X-ray powder diffraction data) close to those of kyzylkumite was found at the Byrud emerald deposit in Norway (Raade and Balić-Žunić, 2006). Its formula is $(\mathrm{Be}, \square)\left(\mathrm{V}^{3+}, \mathrm{Ti}\right)_{3} \mathrm{O}_{6}$. Very large unit-cell dimensions reported for kyzylkumite by discoverers were referred to twining. Raade and Balić-Žunić made an attempt to examine holotype or cotype of kyzylkumite deposited in the Chernyshev Central Geological Research and Survey Museum, St. Petersburg (registration no. 11885); Mineralogical Museum of St. Petersburg Mining Institute, St. Petersburg (registration no. 1197/1); and Mineralogical Museum of St. Petersburg State Uni- versity, St. Petersburg (registration no. 17408) (Smyslova et al., 1981; Pekov, 1998). However, the material had not been received and the researchers purchased specimens of kyzylkumite from collectors and dealers. The grains of kyzylkumite were extremely heterogeneous with inclusions of rutile and other minerals;

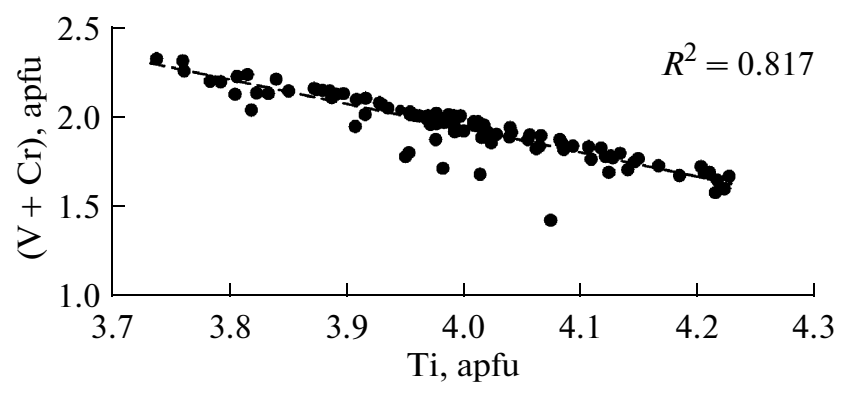

Fig. 9. $(\mathrm{V}+\mathrm{Cr})$ versus Ti in kyzylkumite. 
Table 3. Selected electron microprobe data on kyzylkumite from Sludyanka with elevated content of $\mathrm{Nb}_{2} \mathrm{O}_{5}, \mathrm{WO}_{3}, \mathrm{FeO}$ $\mathrm{Cr}_{2} \mathrm{O}_{3}, \mathrm{SiO}_{2}$, and $\mathrm{CaO}$, wt $\%$

\begin{tabular}{|c|c|c|c|c|c|c|c|c|c|}
\hline Component & 1 & 2 & 3 & 4 & 5 & 6 & 7 & 8 & 9 \\
\hline $\mathrm{SiO}_{2}$ & 0.03 & 0.43 & 0.00 & 0.20 & 0.00 & 0.02 & 0.54 & 0.00 & 0.15 \\
\hline $\mathrm{TiO}_{2}$ & 60.30 & 61.56 & 66.85 & 69.90 & 64.83 & 65.39 & 62.74 & 63.01 & 67.22 \\
\hline $\mathrm{Al}_{2} \mathrm{O}_{3}$ & 0.01 & 0.14 & 0.01 & 0.10 & 0.00 & 0.05 & 0.03 & 0.00 & 0.06 \\
\hline $\mathrm{V}_{2} \mathrm{O}_{3}$ & 29.53 & 30.08 & 26.55 & 24.17 & 25.34 & 28.23 & 23.60 & 22.62 & 27.73 \\
\hline $\mathrm{Cr}_{2} \mathrm{O}_{3}$ & 4.38 & 2.15 & 1.34 & 0.33 & 4.71 & 1.76 & 9.13 & 9.74 & 0.51 \\
\hline $\mathrm{FeO}$ & 0.00 & 0.01 & 0.02 & 0.00 & 1.25 & 0.87 & 0.08 & 0.27 & 0.02 \\
\hline $\mathrm{MnO}$ & 0.02 & 0.01 & 0.01 & 0.01 & 0.00 & 0.02 & 0.01 & 0.02 & 0.01 \\
\hline $\mathrm{MgO}$ & 0.09 & 0.07 & 0.02 & 0.00 & 0.00 & 0.00 & 0.09 & 0.00 & 0.05 \\
\hline $\mathrm{CaO}$ & 0.00 & 0.06 & 0.00 & 0.03 & 0.01 & 0.02 & 0.01 & 0.01 & 0.87 \\
\hline $\mathrm{Nb}_{2} \mathrm{O}_{5}$ & 0.89 & 1.10 & 0.74 & 0.92 & 0.31 & 0.22 & 0.42 & 0.16 & 0.36 \\
\hline $\mathrm{WO}_{3}$ & n.d. & n.d. & 0.50 & 1.21 & n.d. & n.d. & 0.00 & n.d. & 0.00 \\
\hline Total & 95.25 & 95.61 & 96.04 & 96.87 & 96.45 & 96.58 & 96.65 & 95.83 & 96.98 \\
\hline $\mathrm{V}_{2} \mathrm{O}_{3}^{*}$ & 26.18 & 28.35 & 26.55 & 24.17 & 23.66 & 27.23 & 21.54 & 20.43 & 27.73 \\
\hline $\mathrm{VO}_{2}^{*}$ & 3.71 & 1.92 & - & - & 1.86 & 1.10 & 2.28 & 2.42 & - \\
\hline $\mathrm{H}_{2} \mathrm{O}^{*}$ & 3.65 & 3.66 & 3.43 & 3.10 & 3.69 & 3.70 & 3.71 & 3.67 & 3.60 \\
\hline Total & 99.26 & 99.46 & 99.47 & 99.97 & 100.32 & 100.38 & 100.58 & 99.73 & 100.58 \\
\hline \multicolumn{10}{|c|}{ Atoms per formula unit (calculated on the basis of 6 cations and $12 \mathrm{O}$ atoms) } \\
\hline $\mathrm{Si}$ & 0.002 & 0.035 & - & 0.016 & 0.000 & 0.002 & 0.044 & 0.000 & 0.012 \\
\hline $\mathrm{Ti}$ & 3.724 & 3.784 & 4.124 & 4.303 & 3.954 & 3.979 & 3.810 & 3.867 & 4.066 \\
\hline $\mathrm{V}^{4+}$ & 0.221 & 0.114 & - & - & 0.109 & 0.065 & 0.133 & 0.143 & - \\
\hline $\mathrm{V}^{3+}$ & 1.723 & 1.858 & 1.746 & 1.586 & 1.538 & 1.766 & 1.394 & 1.336 & 1.788 \\
\hline $\mathrm{Al}$ & 0.001 & 0.013 & 0.001 & 0.010 & - & 0.005 & 0.003 & - & 0.006 \\
\hline $\mathrm{Cr}$ & 0.284 & 0.139 & 0.087 & 0.021 & 0.302 & 0.113 & 0.583 & 0.628 & 0.032 \\
\hline $\mathrm{Fe}$ & - & 0.001 & 0.001 & - & 0.085 & 0.059 & 0.005 & 0.018 & 0.001 \\
\hline $\mathrm{Mn}$ & 0.001 & 0.001 & 0.001 & 0.001 & - & 0.001 & 0.001 & 0.001 & 0.001 \\
\hline $\mathrm{Mg}$ & 0.011 & 0.009 & 0.002 & - & - & - & 0.011 & - & 0.006 \\
\hline $\mathrm{Ca}$ & - & 0.005 & - & 0.003 & 0.001 & 0.002 & 0.001 & 0.001 & 0.075 \\
\hline $\mathrm{Nb}$ & 0.033 & 0.041 & 0.027 & 0.034 & 0.011 & 0.008 & 0.015 & 0.006 & 0.013 \\
\hline $\mathrm{W}$ & - & - & 0.011 & 0.026 & - & - & - & - & - \\
\hline Total & 6.000 & 6.000 & 6.000 & 6.000 & 6.000 & 6.000 & 6.000 & 6.000 & 6.000 \\
\hline $\mathrm{OH}$ & 2.000 & 2.000 & 1.876 & 1.697 & 2.000 & 2.000 & 2.000 & 2.000 & 1.934 \\
\hline
\end{tabular}

* calculated content.

therefore the structural study of the mineral was failed, but its chemical composition was measured. This composition is given above in Table 2, anal. 16. As indicated by the $\mathrm{TiO}_{2}$ and $\mathrm{V}_{2} \mathrm{O}_{3}$ contents, $\mathrm{Ti} /(\mathrm{V}+\mathrm{Cr}+$ $\mathrm{Fe})$ value, and strongly deficient total, the obtained composition of kyzylkumite substantially differs from that published by discoverers. By analogy with the kyzylkumite-like mineral from the Byrud deposit, the deficient total was ascribed to $4.70 \mathrm{wt} \% \mathrm{BeO}$; the cal- culated empirical formula of kyzylkumite was $\mathrm{Be}_{0.47}\left(\mathrm{Ti}_{2.07} \mathrm{~V}_{0.82}^{3+} \mathrm{Cr}_{0.06} \mathrm{Fe}_{0.04}\right)_{2.99} \mathrm{O}_{6.00}$.

Kyzylkumite is listed among vanadium oxides found in pyrite-pyrrhotite ore at the Vihanti deposit in Finland (Sergeeva et al., 2011). The mineral was identified only on electron microprobe without X-ray diffraction study. The authors reported two very different compositions of the mineral. One of them (wt \%: $58.02 \mathrm{TiO}_{2}, 37.94 \mathrm{~V}_{2} \mathrm{O}_{3}$ ) is readily recalculated to the 
formula of schreyerite and probably belong to precisely this mineral. Another composition with $70.89 \mathrm{wt} \% \mathrm{TiO}_{2}$ is not normalized on the basis of nine $\mathrm{O}$ atoms, i.e., to the formula of schreyerite, but despite obviously overestimated total (Table 2, anal. 17), is consistent with the accepted formula of kyzylkumite.

Having discussed a cause of this difference with the discoverers, Raade and Balić-Žunić assumed that the $\mathrm{X}$-ray diffraction study and measurement of chemical composition of kyzulkumite were carried out by discoverers using nonidentical and insufficiently pure material. Specifically, the chemical composition of this mineral was erroneously determined without account of possible submicroscopic inclusions of rutile and/or tivanite; therefore, the reexamination of the kyzylkumite holotype is required.

The following points should be noted. First, in contrast to the Sludyanka mineral, the kyzylkumitelike mineral from Norway is not kyzylkumite. Although some resemblance to kyzylkumite in the type of oxygen packing, unit-cell dimensions, and character of twining is evident, the crystal structures of these minerals are different. The structure of the mineral from the Byrud emerald deposit is norbergite-type $\left[\mathrm{Mg}_{3} \mathrm{SiO}_{4} \mathrm{~F}_{2}\right]$, whereas in the structure of kyzylkumite, the occupied tetrahedra are absent. Second, the composition of kyzylkumite from Kyzyl Kum analyzed by

Raade and Balić-Žunić, being distinct from the data reported by discoverers, at the same time, is similar to that of kyzylkumite from Sludyanka, compositions of which are mostly deficient in total. Because Be content in the host rocks does not exceed $0.3 \mathrm{ppm}$, enrichment of the Sludyanka mineral in Be is hardly probable. The chemical composition of V-Ti oxide from the Vihanti deposit is also inconsistent with prototype of kyzylkumite, but falls in the compositional range of kyzylkumite from Sludyanka.

At the same time, when kyzylkumite was described for the first time, Smyslova et al. (1981) reported that the electron microprobe analyses were performed for 10 grains in 5-10 points in each grain. The reproducible results would be impossible using such a technique, if the mineral is actually heterogeneous and contains foreign submicroscopic inclusions. In addition, it was indicated that bulk chemical analysis (titration by potassium permanganate and Mohrs' salt) corroborated the absence of $\mathrm{V}^{4+}$ and $\mathrm{V}^{5+}$, i.e., the whole vanadium is trivalent. The overestimated total of $104 \mathrm{wt} \%$ is resulted from normalization to the accepted by us formula of kyzylkumite $\mathrm{Ti}_{4} \mathrm{~V}_{2}^{3+} \mathrm{O}_{10}(\mathrm{OH})_{2}$. In any case, the composition of kyzylkumite from primary source is enigmatic, and following Raade and Balić-Žunić, we think that revision of the kyzylkumite holotype is necessary, and it is desirable to conduct this procedure on the holotype delivered to the museum by discoverers themselves.

\section{REFERENCES}

Armbruster T., Galuskin, E.V., Reznitsky, L.Z., and Sklyarov E.V. X-ray structural investigation of the oxyvanite $\left(\mathrm{V}_{3} \mathrm{O}_{5}\right)$-berdesinskiite $\left(\mathrm{V}_{2} \mathrm{TiO}_{5}\right)$ series: $\mathrm{V}^{4+}$ substituting for octahedrally coordinated $\mathrm{Ti}^{4+}$, Eur. J. Mineral., 2009, vol. 21, no. 4, pp. 885-891.

Armbruster, T., Kadiyski, M., Reznitsky, L.Z., et al., Batisivite, the first silicate related to the derbylite-hemloite group, Eur. J. Mineral., 2008, vol. 20, no. 5, pp. 975-981.

Döbelin, N., Reznitsky, L.Z., Sklyarov E.V., et al., Schreyerite, $\mathrm{V}_{2} \mathrm{Ti}_{3} \mathrm{O}_{9}$ : New occurrence and crystal structure, Am. Mineral., 2006, vol. 91, no. 1, pp. 196-202.

Pekov, I.V. Minerals first discovered in the territory of the former Soviet Union, Moscow: Ocean Pictures Ltd., 1998.

Raade G., Balić-Žunić, T. The crystal structure of $(\mathrm{Be}, \square)(\mathrm{V}, \mathrm{Ti})_{3} \mathrm{O}_{6}$, a mineral related to kyzylkumite, Can. Mineral., 2006, vol. 44, pp. 147-1158.

Reznitsky, L. Z., Sklyarov, E. V., Armbruster T., et al., Batisivite, $\mathrm{V}_{8} \mathrm{Ti}_{6}\left[\mathrm{Ba}\left(\mathrm{Si}_{2} \mathrm{O}\right)\right] \mathrm{O}_{28}$, a new mineral species from the derbylite group, Geol. Ore Deposits, 2008, vol. 50, special issue 7 (Zapisky Russian Mineral. Soc.), pp. 556-564.

Reznitsky, L. Z., Sklyarov, E. V., Armbruster T., et al., Oxyvanite, $\mathrm{V}_{3} \mathrm{O}_{5}$, a new mineral species and the oxyvanite-berdesinskiite $\mathrm{V}_{2} \mathrm{TiO}_{5}$ series from metamorphic rocks of the Slyudyanka Complex, southern Baikal region, Geol. Ore Deposits, 2010, vol. 52, special issue 7 (Zapisky Russian Mineral. Soc.), pp. 574-583.

Sergeeva, N. E., Eremin, N. I., and A. L. Dergachev, Vanadium mineralization in ore of the Vihanti massive sulfide base-metal deposit, Finland, Dokl. Earth Sci., 2011, vol. 436, part 2, pp. 210-212.

Sheldrick, G.M., A short history of SHELX, Acta Crystal., 2008, vol. A64, pp. 112-122.

Smyslova, I.G., Komkov, A.I., Pavshukov, V.V., and Kuznetsova, N.V., Kyzylkumite, $\mathrm{V}_{2} \mathrm{Ti}_{3} \mathrm{O}_{9}$, a new mineral of the group of complex vanadium and titanium oxides, Zap. $V M O, 1981$, no. 5, pp. 607-612.

Translated by I. Baksheev 